\title{
The use of controversial public issues with video and macromedia flash player media in civic education learning
}

\author{
Hendra Hermawan ${ }^{1}$ *, Samsuri Samsuri ${ }^{1}$, Diah Putri Kurniawati ${ }^{1}$, Vinni Sofyaningsih ${ }^{2}$, \\ Danang Prasetyo ${ }^{3}$ \\ ${ }^{1}$ Universitas Negeri Yogyakarta. Jalan Colombo No. 1, Karangmalang, Yogyakarta, 55281, Indonesia \\ ${ }^{2}$ SMK Muhammadiyah Wonosari. Jalan Alun Alun Barat No.11, Wonosari, Gunungkidul, Daerah Istimewa \\ Yogyakarta 55813, Indonesia \\ ${ }^{3}$ Sekolah Tinggi Pariwisata Ambarukmo. Jalan Ahmad Yani, Ringroad Timur 52B, Modalan, Banguntapan, \\ Bantul, Daerah Istimewa Yogyakarta 55198, Indonesia \\ * Corresponding Author. Email: hendra.hermawan.uny@gmail.com
}

Received: 24 August 2018; Revision: 17 September 2018; Accepted: 20 September 2018

\begin{abstract}
The study aimed to find out the effect of controversial public issue learning models with video and Macromedia flash player media on students' critical thinking skills in Civic Education subjects at SMA Negeri 1 Rancah. The particular research was a quasi-experimental research using pretest, posttest control group design. Data analysis techniques used independent t-test and one-way ANOVA test. The results showed that critical thinking skills on students taught using Controversial Public Issues model with video media had a significant effect on the critical thinking ability. This finding might be seen from the one-way ANOVA test results that the $\mathrm{F}_{\text {count }}>\mathrm{F}_{\text {table }}$ $(61.146>3.13)$ or the $\mathrm{p}$-value is lower than $0.05(\mathrm{p}=0.000<0.05)$ and the gain score. The experimental class 1 obtained a gain score of 0.49 in the category of "medium" effectiveness. The experimental class 2 obtained a gain score of 0.34 in the category of "medium" effectiveness. The control class obtained a gain score of 0.00 in the category of "low".
\end{abstract}

Keywords: Problem-based learning model, score clarification technique, learning outcomes

How to Cite: Hermawan, H., Samsuri, S., Kurniawati, D., Sofyaningsih, V., \& Prasetyo, D. (2018). The use of controversial public issues with video and macromedia flash player media in civic education learning. Psychology, Evaluation, and Technology in Educational Research, 1(1), 19-30. Retrieved from http://petier.org/index.php/PETIER/article/view/2

\section{INTRODUCTION}

The critical thinking ability is very important to develop in order the students can analyze and solve the problems, both in the learning process and community life. Critical thinking is an act to see both sides an opinion of on an issue, being open to new evidence that is confirmed by own ideas in the form of reasoning, describing arguments supported by evidence, drawing conclusions from existing facts, solving problems, and others thing related to community (Willingham, 2008). Kalelioğlu \& Gülbahar (2014, p. 248) also stated that critical thinking is a way of thinking or skill by using an information, systematic and thinking approach that is considered logically to decide 'what to do' in dealing the problem. Whereas, the opinion of King, Goodson, \& Rohani $(1998$, p. 1), critical thinking is a component of higher order thinking skills. This ability arises when individuals have experienced new problems that are dilemmatic and must take a decision. This ability produces an explanation on individual knowledge and experience that has functions in solving a problem. Goodson \& Rohani, supported by Kirkley (2003, p. 3), stated that problem-solving involves higher order thinking skills such as visualization, association, abstraction, manipulation, reasoning, analysis, synthesis, and generalization.

A research conducted by Shepelak, Curry-Jackson, \& Moore (1992) showed that critical thinking training might perform by distributing books to students which contains discussion material on problem issues, the students' debate to sharpen the critical thinking skills every week, the students' debate can facilitate to learn the critical thinking skill. Based on research by Pusparatri (2012, p. 27), 
the students' inability in critical thinking is caused by learning strategies implemented in teaching and learning activities. For this reason, problem-based learning is considered a strategy to be used to foster the students' critical thinking skills. Some of the learning models are designed to stimulate students' critical thinking ability and solve problems including learning with problem-based learning.

Problem-based learning is considered able to foster the student creativity or skills, proved by a research by (Murdiono, 2010, p. 14) on improving the Civic Skills through the implementation of problem-based learning strategies. The study concluded that the implementation of problem-based learning strategies in learning Civic Education can improve the civic skills, such critical thinking. Besides the problem-based learning model, Controversial Public Issues (CPI) is also considered to improve the students' critical thinking ability.

Controversial Public Issues (CPI) defined by Hess (2001, p. 1) as "unresolved questions of public policy that spark significant disagreement." From Diana Hess's statement, the CPI Model is able to improve the students' critical thinking ability because the CPI model is used to build the ability to participate in solving problems in a democratic society through discussing. Another study showed that the CPI model can improve the students' critical thinking skills, ie written by Harwood \& Hahn (1990, p. 1) with discussion and conversation on controversial issues allow the students to present shreds of evidence to support an opinion, develops different criticisms and responses from individuals in different individual perspectives.

The approach can support the quality learning of teaching-learning in the classroom. The model hopes can help the students developing an understanding and commitment toward the democratic values, increasing the willingness to participate in political life, and positively influence the understanding of critical thinking skills and interpersonal skills. Educational institutions and classroom teachers have a responsibility to contribute positively, such as giving an opportunity to learn about controversial issues that study the controversial issues with having historical, political, economic, and social sciences on how to design the students to express their own opinions. There are several positive things along learning the current issues, in addition, developing the students' thinking about controversial issues. Supported by Johnson \& Johnson $(1989$, p. 10) that learning the controversial issues increase the student interest to engage in public life, increase the critical thinking and building interpersonal skills. In line with Johnson, a research by Suryanto \& Irmayanti (2015) conducted in Public and Private High Schools in Kediri, East Java Province, found that teachers and students agreed that it is important to integrate the controversial issues of public policy into civic education. By using Controversial Public Issues learning models, teachers can develop students' knowledge of public policy, basic knowledge of orientation, perception, emotion, communication, attitudes, beliefs, and skills to analyze the public policy issues.

According to Kerr, Lines, Blenkinsop, \& Schagen (2001, p. 4), students with a higher level of thinking on civic knowledge, tend to be more expected to participate in political and civil activities like an adult. Therefore, learning models and assessment of learning outcomes of civic education cannot be done only focusing on the cognitive dimension. Referring to Branson (1999, p. 8), the scope of civic education includes civic knowledge, civic skills, and civic disposition. In fact, the implementation of civic education currently dominated by cognitive dimension (civic knowledge) enhancement activities. It impacts on increasing the portion of other dimensions that become neglected and compounded by the limitations of learning media facilities (Sunarso, Dwikusrahmadi, \& Sutarini, 2008, p. 4). A dimension that often neglected is the civic skill. Meanwhile, civic skills provide critical thinking ability that is important to build democratic citizenship (Doğanay, 2012, p. 34). With this statement, the critical thinking ability and learning on controversial issues are a very important aspect for citizens to deal with problems in daily life and state life.

Although the critical thinking ability is important, education in Indonesia, especially in Civic Education subjects there is no application of specific learning assessments to determine and develop the critical thinking skills. Other problems in the field of education according to research by Adnyana (2012, p. 203), student understanding is relatively poor in the context of learning. This condition occurs due to the application of teacher-centered learning. The similar condition also found in research conducted by Wahab (1999, p. 49) on Civics teachers in Sukabumi Regency, Garut Regency, Bandung Regency, and Bandung City. The study found out that generally, teachers used the lecturing and question and answer methods with an assignment. The use of teaching aids is low and limited. Learning only uses talk and chalk models (only lecturing and writing on the blackboard). 
Furthermore, research by Sukini (2009) explained that there are still many teachers who do not perform innovative learning and tends to be passive learning. There are several solutions offered, such as teachers are required to always use auditory learning styles and visual learning styles with the help of learning media in aspects of learning styles. Learning media plays an important role in supporting innovative learning styles and supporting the achievement of learning outcomes. According to Akhtar, Rafaqat, \& Akbar (2015, p. 35), learning media helps educators to deliver knowledge in an impressive way, providing diversity in teaching in the classroom, and making effective learning.

Some technology-based learning media that might use in learning are video media and Macromedia flash player. They are software-based learning media with a 2-dimensional display using computer aids with having a function as an entertainer and educator. In addition, it also helps the visualization process and educators to transfer the knowledge in teaching and learning activities in the classroom. Both media can be used to facilitate explaining the material and problems before audiovisual discussions in order the learning is more interesting with innovative activities. Research by Fathiyati \& Utami $(2012$, p. 1) concluded that the students' responses and students' interests in Macromedia flash player media showed an excellent category.

Macromedia flash player media also categorized as feasible to be used as learning media. Based on research by Anugrah \& Sirait $(2014$, p. 1), learning using Macromedia Flash Player is effective on learning outcomes. Then, research on video conducted by Sudarisman, Masykuri, \& Sudarisman (2013, p. 93), concluded that there was an influence of video media on learning outcomes. In research by Adventina, Sophia B, \& Akbar (2012, p. 9), found out that video media can influence the student participation in class when the teacher presents material to all students.

The merging of learning models, learning media, and the appropriate learning outcomes will produce an output of learning Civic Education in line with the objectives of Civic Education, which students can think critically. Based on research and expert opinions on controversial public issues and learning media of Macromedia flash player and video, there has been no empirical study on the influence of video media and Macromedia flash player to improve critical thinking skills. In this case, the researcher tries to find out the influence of controversial public issues with video media and Macromedia Flash Player on students' thinking skills. Therefore, the researcher conducted research with the title of the influence using controversial public issues with video media and Macromedia flash player on the critical thinking ability in the Civic Education learning in SMA Negeri 1 Rancah.

\section{METHOD}

The particular study used a quantitative approach with quasi-experimental research methods. Experiments carried out on learning using controversial public issues with video media and Macromedia flash player. It aimed to find out the differences critical thinking ability in Civics Education in the material "Analyzing the equal position of citizens in the life of society, nation and state," grade X students of SMA Negeri 1 Rancah. The research design was pretest-posttest control group design.

This research conducted on January 13, 2016, to February 18, 2016. The research was carried out at SMA Negeri 1 Rancah, Cimais Regency, West Java Province. The population was students of grade X SMA N 1 Rancah totaling 9 classes. Sampling selection technique carried out by simple random sampling due to the population considered as homogeneous. There were two experimental classes and a control class; class X3 (experimental class 1), class X4 (experimental class 2), and class X5 (control class). The experimental class 1 consisted of 28 students. The experimental class 2 consisted of 26 students. And the control class consisted of 28 students. Pre-test conducted before the research both in the experimental class (treatment) and a control class to determine the students' initial abilities. The experimental class applied to learn using the CPI model with video media and Macromedia flash player. Meanwhile, the control class applied to learn using conventional models (lecturing) or without using the CPI model with video media and Macromedia flash player.

The study on the learning process carried out for three meetings/face-to-face meetings. This action is in line with the curriculum syllabus and Lesson plan for grade X. The experimental class and control class treated according to the determined learning model. After the pretest, students divided into groups. Furthermore, in the experimental class, the teacher treated the students with the CPI model with video media (experiment 1) and Macromedia Flash Player (experiment 2), with the topic on the issue of naturalization and the release of citizenship status. After a certain period of treatment, 
posttest conducted to measure the learning outcomes, both in the control class and the experimental class.

Data collection techniques and instruments used tests and observations. The test instruments were description tasks aiming to measure the critical thinking ability, and observation instrument using class observation sheets aiming to determine the activeness and students' critical thinking skills in the classroom. Civics learning material in this study was "Analyzing the equality of citizens in the life of society, nation and state".

Observation techniques aimed to collect learning outcomes data on aspects of student attitudes and skills. The measured attitudes in this particular study were spiritual attitude and social attitude. Spiritual attitude is a competence that must in every subject of learning. The measured social attitudes through this observation were the attitude of discipline and the attitude of tolerance of students. Discipline and tolerance measured relating to the civic disposition and must have by every citizen.

Learning outcomes in the realm of skills measured through observation on the presentation of students' work as an effort to communicate with civic learning and aimed to develop the civic skills competencies which are components of civic competence. The assessed aspects on skills competency are the ability to give opinions, arguments, and criticisms, as well as the ability to ask questions. Besides these abilities, other aspects are using speaking and using good language. Learning outcomes of skills competencies are the outcome from understanding the aspects of knowledge and manifestations of attitude aspects.

In the development, civic skills described as participatory and involvement skills. The developed competencies are the ability of involvement and public participation which are components of citizenship competency that focuses on the ability to identify what actions will be taken in a mass situation or solve the citizenship problems. Students must have the ability to listen to the other perspectives in taking a stand or action and mobilizing other citizens to perform the same action.

Data analysis techniques used the t-test, analysis of variance (Anova), and gain score. A discrimination test of t-test is used to determine whether two unrelated samples have different averages. The discrimination test of t-test is performed by comparing the two-average score with the standard error of the two sample differences. The hypothesis test aimed to determine the differences in students learning outcomes between experimental classes (PBM models using score clarification techniques) and control classes (PBM models without score clarification techniques). The normalized gain score $<\mathrm{g}>$ technique was used to determine the effectiveness of student learning outcomes.

\section{FINDINGS AND DISCUSSION}

\section{Pretest the Critical Thinking Skills in the Experiment Class 1}

The test of critical thinking skills in this study consisted of 5 questions in the form of descriptions. The determination of the tendency of pretest data on critical thinking skills referred to the curriculum 2013 criteria which divided into 4 categories. Table 1 is a distribution of the tendency of pretest data of critical thinking skills based on the test in the experimental class 1:

Table 1. The distribution of the tendency of pretest data of critical thinking skills based on the test in the experimental class 1

\begin{tabular}{ccccc}
\hline No. & Score & Frequency & Percentage $\%$ & Category \\
\hline 1. & $3,20-400$ & 0 & 0 & Excellent \\
2. & $2,80-3,19$ & 1 & $3,8 \%$ & Good \\
3. & $2,40-2,79$ & 0 & 0 & Enough \\
4. & $<2,40$ & 25 & $96,2 \%$ & Poor \\
& Total & 26 & $100 \%$ & \\
\hline
\end{tabular}

(Source: Primary Data, 2016)

Based on table 1, the tendency of the critical thinking skills based on the test in the experiment class 1 is $96.2 \%$ of students in the poor category and $3.8 \%$ of students in the good category.

\section{Posttest the Critical Thinking Skills in the Experiment Class 1}

The determination of the tendency of posttest data on critical thinking skills referred to the Curriculum 2013 criteria which divided into 4 categories. Table 2 is a distribution of the tendency of posttest data of critical thinking skills based on the test in the experimental class 1: 
Psychology, Evaluation, and Technology in Educational Research, 1 (1), 2018, 23

Hendra Hermawan, Samsuri Samsuri, Diah Putri Kurniawati, Vinni Sofyaningsih, Danang Prasetyo

Table 2. The distribution of the tendency of posttest data of critical thinking skills based on the test in the experimental class 1

\begin{tabular}{ccccc}
\hline No. & Score & Frequency & Percentage $\%$ & Category \\
\hline 1. & $3,20-400$ & 8 & $30,8 \%$ & Excellent \\
2. & $2,80-3,19$ & 3 & $11,5 \%$ & Good \\
3. & $2,40-2,79$ & 8 & $30,8 \%$ & Enough \\
4. & $<2,40$ & 7 & $26,9 \%$ & Poor \\
\end{tabular}

(Source: Primary Data, 2016)

Based on Table 2, the tendency of critical thinking skills based on the test in the experimental class 1 is $30.8 \%$ of students in the excellent category, $11.5 \%$ in the good category, $30.8 \%$ of students in enough category, and $26.9 \%$ of students in the poor category. This means, that (1) students already have sufficient understanding on the equal position among citizens in the life of society, nation, and state, (2) students have not been able to describe the foundation of equality among citizens in the life of society, nation and state, and 3) students have not been able to provide examples of behavior on the equal position among citizens in the life of society, nation and state.

\section{Observation the Critical Thinking Skill in the Experiment Class 1}

The determination of the tendency of observation data on critical thinking skills referred to the curriculum 2013 criteria which divided into 4 categories. Table 3 is a distribution of the tendency of posttest data of critical thinking skills based on observation in the experimental class 1 :

Table 3. Distribution of the tendency of posttest data of critical thinking skills based on observation in the experimental class 1

\begin{tabular}{ccccc}
\hline No. & Score & Frequency & Percentage $\%$ & Category \\
\hline 1. & $3,20-400$ & 10 & $38,5 \%$ & Excellent \\
2. & $2,80-3,19$ & 3 & $11,5 \%$ & Good \\
3. & $2,40-2,79$ & 8 & $30,8 \%$ & Enough \\
4. & $<2,40$ & 5 & $19,2 \%$ & Poor \\
& Total & 26 & $100 \%$ & \\
\hline
\end{tabular}

(Source: Primary Data, 2016)

Based on Table 3, the tendency of critical thinking skills based on the observation in the experimental class 1 is $38.5 \%$ of students in the excellent category, $11.5 \%$ in the good category, $30.8 \%$ of students in enough category, and $19.2 \%$ of students in the poor category. In sum, the majority of critical thinking skills based on the results of observations in the experimental class 1 using the Controversial Public Issues learning model with video media are in excellent categories. This means that students have excellent skills in analyzing problems, focusing problems, finding information, communicating problems, giving opinions on the topic, appreciating different opinions, providing alternative solutions of problems in the topic of discussion and able to choose the right solution in solving problems to strengthen the students' critical thinking skills.

\section{Experiment Class 2}

\section{Pretest the Critical Thinking Skills in the Experiment Class 2}

Table 4. Distribution of the tendency of pretest data of critical thinking skills based on the test in the experimental class 2

\begin{tabular}{ccccc}
\hline No. & Score & Frequency & Percentage $\%$ & Category \\
\hline 1. & $3,20-400$ & 1 & $4,2 \%$ & Excellent \\
2. & $2,80-3,19$ & 1 & $4,2 \%$ & Good \\
3. & $2,40-2,79$ & 1 & $4,2 \%$ & Enough \\
4. & $<2,40$ & 21 & $87,5 \%$ & Poor \\
& Total & 24 & $100 \%$ & \\
\hline
\end{tabular}

(Source: Primary Data, 2016)

The pretest of critical thinking skills in the experiment class 2 consisted of 5 questions in the form of descriptions. The determination of the tendency of pretest data on critical thinking skills 
referred to the Curriculum 2013 criteria which divided into 4 categories. Table 4 is a distribution of the tendency of pretest data of critical thinking skills based on the test in the experimental class 2 .

Based on table 4, the tendency of critical thinking skills based on the pretest in the experimental class 2 is $4.2 \%$ of students in the excellent category, $4.2 \%$ in the good category, $4.2 \%$ of students in enough category, and $87.5 \%$ of students in the poor category. In sum, the majority of critical thinking skills based on the pretest results in the experimental class 2 are in the poor categories. This means, that (1) students have poor understanding on the equal position among citizens in the life of society, nation, and state, (2) students have not been able to describe the foundation of equality among citizens in the life of society, nation and state, and (3) students have not been able to provide examples of behavior on the equal position among citizens in the life of society, nation and state.

\section{Posttest the Critical Thinking Skills in the Experiment Class 2}

The determination of the tendency of posttest data on critical thinking skills referred to the Curriculum 2013 criteria which divided into 4 categories. Table 5 is a distribution of the tendency of posttest data of critical thinking skills based on observation in the experimental class 2:

Table 5. Distribution of the tendency of posttest data of critical thinking skills based on test in the experimental class 2

\begin{tabular}{ccccc}
\hline No. & Score & Frequency & Percentage $\%$ & Category \\
\hline 1. & $3,20-400$ & 3 & $12,5 \%$ & Excellent \\
2. & $2,80-3,19$ & 13 & $54,2 \%$ & Good \\
3. & $2,40-2,79$ & 5 & $20,8 \%$ & Enough \\
4. & $<2,40$ & 3 & $12,5 \%$ & Poor \\
\end{tabular}

(Source: Primary Data, 2016)

Based on table 5, the posttest of critical thinking skills based on the test in the experimental class 2 is $12.5 \%$ of students in the excellent category, $54.2 \%$ in the good category, $20.8 \%$ of students in enough category, and $12.5 \%$ of students in the poor category. In sum, the results of posttest in the experimental class 2 using the Controversial Public Issues learning model with Macromedia flash player treated the students to have excellent understanding on the equal position among citizens in the life of society, nation, and state, have not been able to describe the foundation of equality among citizens in the life of society, nation, and state, and have not been able to provide examples of behavior on the equal position among citizens in the life of society, nation and state.

\section{Observation the Critical Thinking Skill in the Experiment Class 2}

The determination of the tendency of observation data on critical thinking skills referred to the Curriculum 2013 criteria which divided into 4 categories. Table 6 is a distribution of the tendency of observation data of critical thinking skills based on observation in the experimental class 2:

Table 6. Distribution of the tendency of observation data of critical thinking skills based on observation in the experimental class 2

\begin{tabular}{ccccc}
\hline No. & Score & Frequency & Percentage $\%$ & Category \\
\hline 1. & $3,20-400$ & 1 & $4,2 \%$ & Excellent \\
2. & $2,80-3,19$ & 6 & $25,0 \%$ & Good \\
3. & $2,40-2,79$ & 7 & $29,2 \%$ & Enough \\
4. & $<2,40$ & 10 & $41,7 \%$ & Poor \\
\hline
\end{tabular}

(Source: Primary Data, 2016)

Based on Table 6 , the critical thinking skills based on the observation in the experimental class 2 is $4.2 \%$ of students in the excellent category, $25.0 \%$ in the good category, $29.2 \%$ of students in enough category, and $41.7 \%$ of students in the poor category. This means that students have excellent skills in analyzing problems, focusing problems, finding information, communicating problems, giving opinions on the topic, appreciating different opinions, providing alternative solutions of problems in the topic of discussion and able to choose the right solution in solving problems to strengthen the students' critical thinking skills. 


\section{Control Class}

\section{Pretest the Critical Thinking Skills in the Control Class}

The total subject of pretest in the control class was 26 students. The test consisted of 5 essay questions. The determination of the tendency of pretest data on critical thinking skills referred to the Curriculum 2013 criteria which divided into 4 categories. Table 7 is a distribution of the tendency of pretest data of critical thinking skills based on observation in the control class:

Table 7. Distribution of the tendency of pretest of critical thinking skills based on test in the control class

\begin{tabular}{ccccc}
\hline No. & Score & Frequency & Percentage $\%$ & Category \\
\hline 1. & $3,20-400$ & 0 & $0 \%$ & Excellent \\
2. & $2,80-3,19$ & 0 & $0 \%$ & Good \\
3. & $2,40-2,79$ & 3 & $11,5 \%$ & Enough \\
4. & $<2,40$ & 23 & $88,5 \%$ & Poor \\
& Total & 26 & $100 \%$ & \\
\hline
\end{tabular}

(Source: Primary Data, 2016)

Based on table 7, the tendency of critical thinking skills based on the test in the control class is $88.5 \%$ of students in the excellent category and $11.5 \%$ in enough category. In sum, the majority of critical thinking skills based on the pretest results in the control class are in the poor categories. This means, that (1) students have poor understanding on the equal position among citizens in the life of society, nation, and state, (2) students have not been able to describe the foundation of equality among citizens in the life of society, nation and state, and (3) students have not been able to provide examples of behavior on the equal position among citizens in the life of society, nation and state.

Posttest the Critical Thinking Skills in the Control Class

The total subject of posttest in the control class was 26 students. The determination of the tendency of posttest data on critical thinking skills referred to the curriculum 2013 criteria which divided into 4 categories. Table 8 is a distribution of the tendency of posttest data of critical thinking skills based on the test in the control class:

Table 8. Distribution of the tendency of posttest data of critical thinking skills based on the test in the control class

\begin{tabular}{ccccc}
\hline No. & Score & Frequency & Percentage $\%$ & Category \\
\hline 1. & $3,20-400$ & 2 & $7,7 \%$ & Excellent \\
2. & $2,80-3,19$ & 3 & $11,5 \%$ & Good \\
3. & $2,40-2,79$ & 6 & $23,1 \%$ & Enough \\
4. & $<2,40$ & 15 & $57,7 \%$ & Poor \\
& Total & 26 & $100 \%$ & \\
\hline
\end{tabular}

(Source: Primary Data, 2016)

Based on table 8 , the posttest tendency of critical thinking skills based on the test in the control class is $7.7 \%$ of students in the excellent category, $11.5 \%$ in the good category, $23.1 \%$ of students in enough category and $57.7 \%$ of students in the poor category. In sum, the model and conventional media impact the students of (1) poor understanding on the equal position among citizens in the life of society, nation, and state, (2) have not been able to describe the foundation of equality among citizens in the life of society, nation and state, and (3) have not been able to provide examples of behavior on the equal position among citizens in the life of society, nation and state.

\section{Observation the Critical Thinking Skills in the Experiment Class 2}

The determination of the tendency of observation data on critical thinking skills referred to the Curriculum 2013 criteria which divided into 4 categories. Table 9 is a distribution of the tendency of observation data of critical thinking skills based on the test in the control class.

Based on Table 9, the critical thinking skills based on the observation in the control class is $96.2 \%$ of students in the poor category, $25.0 \%$ and $3.8 \%$ of students in enough category. This means that the model and conventional media impact the students' skills in analyzing problems, focusing problems, finding information, communicating problems, giving opinions on the topic, appreciating 
different opinions, providing alternative solutions of problems in the topic of discussion and able to choose the right solution in solving problems to strengthen the students' critical thinking skills.

Table 9. Distribution of the tendency of observation the critical thinking skills based in the control class

\begin{tabular}{ccccc}
\hline No. & Score & Frequency & Percentage $\%$ & Category \\
\hline 1. & $3,20-400$ & 0 & $0 \%$ & Excellent \\
2. & $2,80-3,19$ & 0 & $0 \%$ & Good \\
3. & $2,40-2,79$ & 1 & $3,8 \%$ & Enough \\
4. & $<2,40$ & 25 & $96,2 \%$ & Poor \\
\hline
\end{tabular}

(Source: Primary Data, 2016)

\section{Results of Hypothesis Test}

\section{Prerequisites for Hypothesis Test Analysis}

Normality Test

The variable normality test was using Kolmogorov Smirnov test. The normality criteria are; the significance value of the calculation is higher than $\alpha=0.05$, the distribution is normal, or on the contrary, if the value of the calculation is smaller than $\alpha=0.05$, the distribution is not normal. Table 10 presents the results of calculations on all variables in table 7 .

Table 10. Summary of Normality Test Results

\begin{tabular}{clcl}
\hline No. & \multicolumn{1}{c}{ Data } & Sig $(\mathrm{p})$ & \multicolumn{1}{c}{ Description } \\
\hline 1. & Pretest the experiment 1 & 0,545 & Significance $>0,05=$ normal \\
2. & Posttest the experiment 1 & 0,534 & Significance $>0,05=$ normal \\
3. & Pretest the experiment 2 & 0,318 & Significance $>0,05=$ normal \\
4. & Posttest the experiment 2 & 0,355 & Significance $>0,05=$ normal \\
5. & Pretest the control class & 0,802 & Significance $>0,05=$ normal \\
6. & Posttest the control class & 0,662 & Significance $>0,05=$ normal \\
\hline
\end{tabular}

(Source: Primary Data, 2016)

Based on the results of the SPSS program calculation, the data distribution was normal. It was normal distribution based on the results of the normality test calculation because it has a significance value higher than 0.05 in $(\mathrm{p}>0.05)$. So, this data has met the requirements for analysis.

Homogeneity Test

After the normality nest to the data distribution, continued to homogeneity tests. With the assistance of the SPSS program, the scores were homogeneous variance. The requirement of homogeneous variance has met when the significance score is higher than 0.05 or $\mathrm{t}_{\text {count }}<\mathrm{t}_{\text {table. }}$. Table 11 presents the results of the homogeneity test in Table 12.

Table 11. Summary of Homogeneity Test Results

\begin{tabular}{clccccc}
\hline No. & Data & F count & F table & $\mathrm{db}$ & Sig & Description \\
\hline 1. & Pretest the critical thinking skills & 0,854 & 3,13 & $2: 73$ & 0,430 & Homogeneity \\
2. & Posttest the critical thinking skills & 2,961 & 3,13 & $2: 73$ & 0,058 & Homogeneneity \\
\hline
\end{tabular}

(Source: Primary Data, 2014)

Based on the calculation results of the variable homogeneity test with the assistance of SPSS program showed that the data has a homogeneous variance because the significance value is higher than $5 \%(\mathrm{p}>0.05)$ or has $\mathrm{t}_{\text {count }}<\mathrm{t}_{\text {table. }}$. So, the data has met the requirements for analysis.

Hypothesis Test

\section{First Hypothesis}

The first hypothesis is "the application of the Controversial Public Issues learning model with video media in civic education learning influences to the students' critical thinking skills in civic education learning in SMA 1 Rancah.” The analysis used t-test. Table 12 presents the results of the ttest on students' critical thinking skills in the experimental class 1 and the control class. 
Psychology, Evaluation, and Technology in Educational Research, 1 (1), 2018, 27

Hendra Hermawan, Samsuri Samsuri, Diah Putri Kurniawati, Vinni Sofyaningsih, Danang Prasetyo

Table 12. Summary the results of the t-test on students' critical thinking skills in the experimental class 1 and the control class.

\begin{tabular}{ccccc}
\hline Data & Mean & Sig & t count & Description \\
\hline Pretest Experiment 1 & 2.84 & 0.000 & 9,863 & Significance $(\mathrm{P}=0,000<0,05)$ \\
Pretest Control & 1.75 & & & \\
\hline
\end{tabular}

(Source: Primary Data, 2016)

Based on Table 12, the score of $t_{\text {count }}$ is 9.863 and the score of $t_{\text {table }}$ with $\mathrm{db} 50$ at the $5 \%$ significance level of 2.021. The score of $t_{\text {count }}>t_{\text {table }}$ or $p$-value is smaller than $0.05(p=0.000<0.05)$. The score indicated that there are differences in critical thinking skills between students treated with Controversial Public Issues learning models with video media (experimental class) and conventional learning models (control class). The gain score in the experimental class using the Controversial Public Issues learning model with video media was 0.49 in the medium effectiveness category. Meanwhile, the gain score in the control class treated using conventional learning models was 0.00 in the poor effectiveness category.

Based on the results, the hypothesis accepted, ie the application of the Controversial Public Issues learning model with video media in civic education learning influence on students' critical thinking skills in civic education learning in SMA Negeri 1 Rancah.

\section{Second Hypothesis}

The second hypothesis in this study is "the application of the Controversial Public Issues learning model with Macromedia Flash Player in civic education learning influences to the students' critical thinking skills in civic education learning in SMA 1 Rancah." The analysis used t-test. Table 13 presents the results of the t-test of students' critical thinking skill in the experiment class 2 and the control class.

Table 13. Summary the results of the t-test on students' critical thinking skills in the experiment class 2 and the control class.

\begin{tabular}{lcccc}
\hline \multicolumn{1}{c}{ Data } & Mean & Sig & t count & Description \\
\hline $\begin{array}{l}\text { Pretest The Experiment 2 } \\
\text { (CPI Model with Macromedia Flash Player) }\end{array}$ & 2.63 & 0.000 & 9,341 & Significance \\
Pretest the Control (Convensional Model) & & & & $(\mathrm{P}:=0,000<0,05)$ \\
\hline
\end{tabular}

(Source: Primary Data, 2016)

Based on Table 13, the score of $t_{\text {count }}$ is 9.341 and the score of $t_{\text {table }}$ with $\mathrm{db} 48$ at the $5 \%$ significance level of 2.021. The score of $t_{\text {count }}>t_{\text {table }}$ or $p$-value is smaller than $0.05(p=0.000<0.05)$. The score indicated that there are differences in critical thinking skills between students treated using Controversial Public Issues learning models with Macromedia Flash Player (experimental class) and conventional learning models (control class). The gain score in the experimental class using the Controversial Public Issues learning model with Macromedia Flash Player was 0.34 in the medium effectiveness category. Meanwhile, the gain score in the control class treated using conventional learning models was 0.00 in the poor effectiveness category.

Based on the results, the hypothesis accepted, ie the application of the Controversial Public Issues learning model with Macromedia Flash Player in civic education learning influence on students' critical thinking skills in civic education learning in SMA Negeri 1 Rancah.

\section{Third Hypothesis}

Table 14. Summary the results of One way Aova on students' critical thinking skills in the experiment class 1,

Experiment Class 2, and the control class.

\begin{tabular}{lcccc}
\hline \multicolumn{1}{c}{ Data } & Mean & Sig & t count & Description \\
\hline $\begin{array}{l}\text { Pos the critical thinking skill in the experiment 1 (CPI Model } \\
\text { with Video media) }\end{array}$ & 2,84 & & & \\
$\begin{array}{l}\text { Pos the critical thinking skill in the experiment 2 (CPI Model } \\
\text { with Macromedia Flash Player) }\end{array}$ & 2,62 & & & \\
$\begin{array}{l}\text { Pos the critical thinking skill in the control class } \\
\text { (Convensional Model) }\end{array}$ & 1,75 & & & Significance $(\mathrm{P}=$ \\
\end{tabular}

(Source: Primary Data, 2016) 
The third hypothesis in this study is "there are differences the application of the Controversial Public Issues learning a model with video media and Macromedia Flash Player to the students' critical thinking skills in civic education learning in SMA 1 Rancah, Ciamis Regency." The analysis used oneway ANOVA with SPSS. The significance criteria are p-value is smaller than 0.05 . Table 14 presents the results of one-way ANOVA of students' critical thinking skill in the experiment class 1, experiment class 2 and the control class.

Based on Table 14, the score of $\mathrm{t}_{\text {count }}$ is 61.146 and the score of $\mathrm{t}_{\text {table }}$ with $\mathrm{db} 2: 73$ at the $5 \%$ significance level of 3.13. The score of $t_{\text {count }}>t_{\text {table }}$ or $p$-value is smaller than $0.05(p=0.000<0.05)$. The score indicated that there are differences in critical thinking skills between students treated with Controversial Public Issues learning models with video media, Macromedia Flash Player (experimental class) and conventional learning models (control class). Table 15 present the gain scores of the learning model.

Table 15. Results of Gain Score of Learning Outcome

\begin{tabular}{lcc}
\hline \multicolumn{1}{c}{ Class } & Gain Score & Category \\
\hline $\begin{array}{l}\text { Experiment 1 } \\
\text { (CPI Learning Model with Video media) }\end{array}$ & 0.49 & Medium Effectiveness \\
$\begin{array}{l}\text { Eksperimen 2 } \\
\text { (CPI Learning Model with Macromedia Flash Player) }\end{array}$ & 0.34 & Medium Effectiveness \\
$\begin{array}{l}\text { Kontrol } \\
\text { (Convensional Model) }\end{array}$ & 0.00 & Poor Effectiveness \\
\hline
\end{tabular}

(Source: Primary Data, 2016)

Table 15 showed that students treated using Controversial Public Issues learning model with video media gained a gain score of 0.49 in the medium effectiveness category. Students treated using Controversial Public Issues learning model with Macromedia Flash Player gained a gain score of 0.34 in the medium effectiveness category. And, students treated using a conventional model in the control class gained a gain score of 0.00 in the poor effectiveness category.

The assessment of critical thinking skill consisted of test assessment and observation. The comparison between the gain score of critical thinking skill based on test and observation presents in Figure 1.

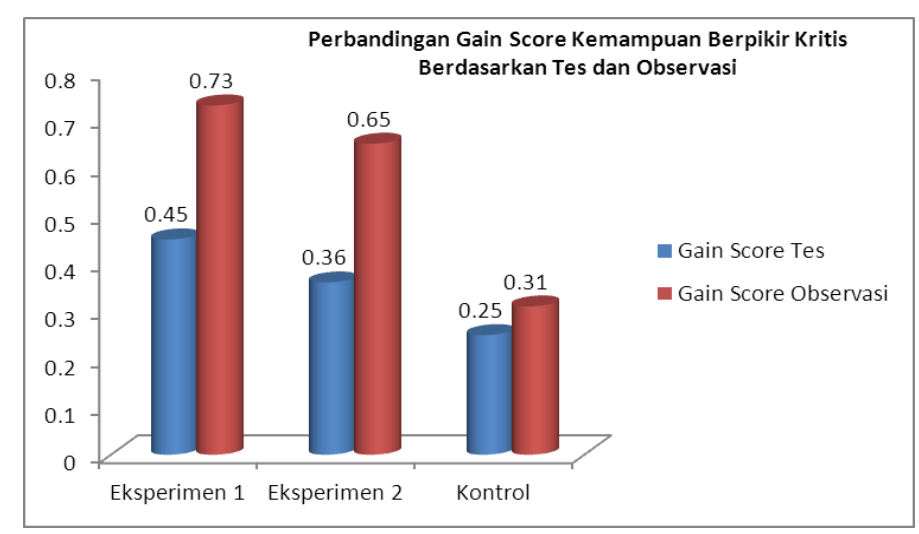

Figure 1. The comparison of gain score based on test and observation

Based on Figure 1, the gain score based on tests and observations in the experiment class 1 (Controversial Public Issues learning model with video media) is higher than experiment class 2 (Controversial Public Issues learning model with Macromedia Flash Player) and control class (conventional).

The comparison result of the mean (average score) also showed that students in the experiment class 1 are better than the experimental class 2 and the control class. The students in the experiment class 1 at pretest obtained a mean score of 1.78. After treated Controversial Public Issues learning model with video media, the score increased into 2.84. The students in the experiment class 2 at pretest obtained a mean score of 1.87. After treated Controversial Public Issues learning model with Macromedia Flash Player, the score increased into 2.62. And, students in the control class at pretest obtained a mean score of 1.71. After treated conventional learning models, the score increased into 1.75. The comparison results of the average score are presented in Figure 2: 


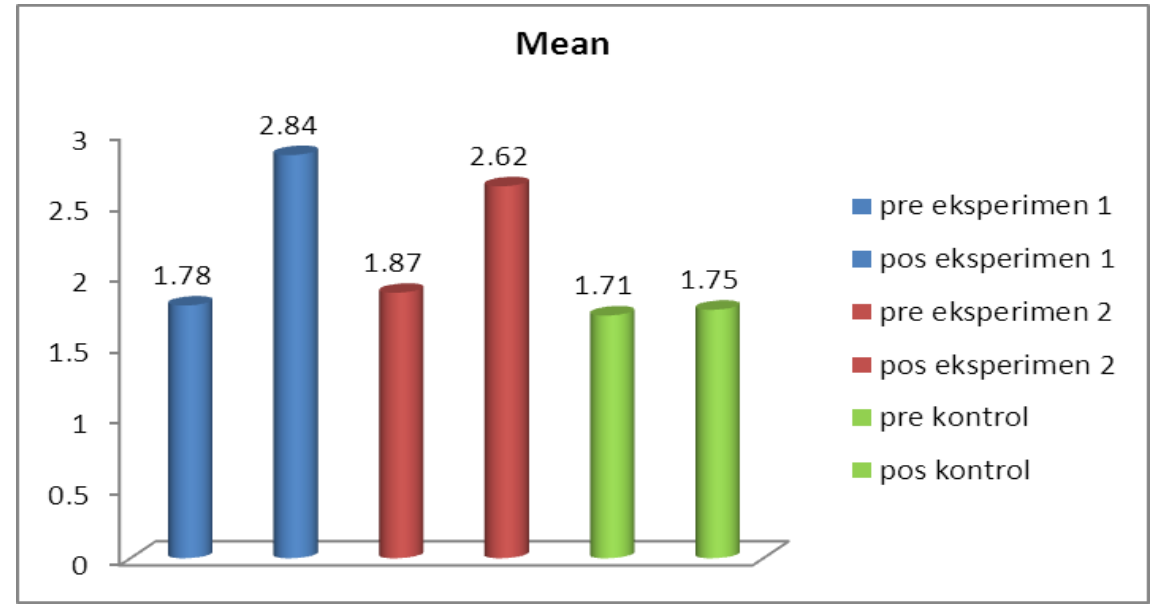

Figure 2. Comparison of Mean

The categorization results of critical thinking skills in this study also showed that the experiment class 1 treated using Controversial Public Issues learning model with video media was better than those treated using Controversial Public Issues learning model with Macromedia Flash Player and conventional model.

Based on the results, the hypothesis accepted, ie the application of the Controversial Public Issues learning model with video media in civic education learning influence on students' critical thinking skills in civic education learning in SMA Negeri 1 Rancah. This conclusion based on the test result of one-way ANOVA, mean score and gain score.

\section{CONCLUSION}

The application of Controversial Public Issues learning model with video media and Macromedia Flash Player has an effect on students' critical thinking skills in Civics subjects on the basic competence of "Describing the position of citizens and citizenship" at SMA Negeri 1 Rancah. The results showed that the application of Controversial Public Issues with video media has a better influence on students' critical thinking skills in Civics Education at SMA N 1 Rancah. The conclusion based on the one-way ANOVA test results which showed that the Fcount $>$ Ftable (61.146>3.13) or pvalue is smaller than $0.05(\mathrm{p}=0.000<0.05)$. Students treated using Controversial Public Issues learning model with video media gained a gain score of 0.49 (experimental class 1). Students treated Controversial Public Issues learning model with Macromedia Flash Player (experimental class 2) gained a gain score of 0.34 . And, students treated using conventional learning models (control class) gained a gain score of 0.00 .

\section{REFERENCES}

Adnyana, G. P. (2012). Keterampilan berpikir kritis dan pemahaman konsep siswa pada model siklus belajar hipotetis deduktif. Jurnal Pendidikan Dan Pengajaran, 45(3). https://doi.org/10.23887/JPPUNDIKSHA.V45I3.1833

Adventina, A., Sophia B, T. C., \& Akbar, U. (2012). The effectiveness of using video of expression as the media in improving speaking ability in making giving instruction expression for 7A class of Theresiana 1 Junior High School. ETERNAL (English Teaching Journal), 2(2). https://doi.org/10.26877/eternal.v2i2.432

Akhtar, A., Rafaqat, N., \& Akbar, A. (2015). Use of media for effective instruction its importance: Some consideration. Journal of Elementary Education , 18(2), 35-40. Retrieved from http://pu.edu.pk/images/journal/JEE/PDF-Files/JEE-18(1-2) No_3.pdf

Anugrah, G. R., \& Sirait, M. (2014). Effect of cooperative type STAD aided by macromedia flash toward students' learning outcomes. INPAFI (Inovasi Pembelajaran Fisika), 2(1). https://doi.org/10.24114/INPAFI.V2I1.1944

Branson, M. S. (1999). Belajar civic education dari Amerika. Yogyakarta: Kerja LKIS dan The Asia Foundation. 
Doğanay, A. (2012). A curriculum framework for active democratic citizenship education. In Schools, Curriculum and Civic Education for Building Democratic Citizens (pp. 19-39). Rotterdam: SensePublishers. https://doi.org/10.1007/978-94-6209-167-2_3

Fathiyati, R., \& Utami, R. P. (2012). Pengembangan media pembelajaran biologi berbasis macromedia flash sebagai sumber belajar bagi siswa SMA/MA kelas XI semester 2 materi pokok sistem reproduksi manusia. Prosiding Seminar Nasional Biologi, 9(1). Retrieved from http://jurnal.fkip.uns.ac.id/index.php/prosbio/article/view/1081

Harwood, A. M., \& Hahn, C. L. (1990). Controversial issues in the classroom. ERIC Digest.

Hess, D. (2001). Teaching students to discuss controversial public issues. Retrieved from http://www.indiana.edu/ ssdc/cpidig.htm

Johnson, D. W., \& Johnson, R. T. (1989). Cooperation and competition: Theory and research. Interaction Book Company.

Kalelioğlu, F., \& Gülbahar, Y. (2014). The effect of instructional techniques on critical thinking and critical thinking dispositions in online discussion. Educational Technology \& Society (Vol. 17). Retrieved from https://www.j-ets.net/ETS/journals/17_1/21.pdf

Kerr, D., Lines, A., Blenkinsop, S., \& Schagen, I. (2001). Citizenship and education at age 14: A summary of the international findings and preliminary results for England. Slough, National Foundation for Educational Research \& London, Department for Education and Employment.

King, F. J., Goodson, L., \& Rohani, F. (1998). Higher order thinking skills: Definition, teaching strategies, assessment.

Kirkley, J. (2003). Principles for teaching problem solving. Retrieved from http://www.cimm.ucr.ac.cr/resoluciondeproblemas/PDFs/Kirkley, Jamie. 2003.pdf

Murdiono, M. (2010). Peningkatan keterampilan kewarganegaraan (civic skills) melalui penerapan strategi pembelajaran berbasis masalah. Jurnal Penelitian Ilmu Pendidikan, 3(1). https://doi.org/10.21831/JPIPFIP.V0I0.4624

Pusparatri, R. K. D. (2012). Strategi pembelajaran berbasis masalah untuk meningkatkan kemampuan berpikir kritis siswa. Jurnal Ilmiah Guru Caraka Olah Pikir Edukatif, 16(2). Retrieved from https://journal.uny.ac.id/index.php/cope/article/view/3961

Shepelak, N. J., Curry-Jackson, A., \& Moore, V. L. (1992). Critical thinking in introductory sociology classes: A program of implementation and evaluation. Teaching Sociology, 20(1), 18-27.

Sudarisman, T. A., Masykuri, M., \& Sudarisman, S. (2013). Pembelajaran biologi menggunakan pendekatan CTL (contextual teaching and learning) melalui media flipchart dan video ditinjau dari kemampuan verbal dan gaya belajar. BIOEDUKASI, 6(2). Retrieved from http://jurnal.fkip.uns.ac.id/index.php/biologi/article/view/5534

Sukini, S. (2009). Pengaruh pendidikan kesehatan tentang napza terhadap pengetahuan dan sikap siswa kelas III SMK Muhammadiyah Kartasura. Universitas Muhammadiyah Surakarta. Retrieved from http://eprints.ums.ac.id/3992/

Sunarso, S., Dwikusrahmadi, S., \& Sutarini, Y. C. N. (2008). Pendidikan Kewarganegaraan PKN untuk perguruan tinggi. Yogyakarta: UNY Press.

Suryanto, S., \& Irmayanti, E. (2015). Analysis of the reasons of teaching controversial issues on public policy to the senior high school students. Journal of Education and Practice, 6(36), 56-60. Retrieved from https://iiste.org/Journals/index.php/JEP/article/view/27930

Wahab, A. A. (1999). Pengembangan konsep dan paradigma pendidikan kewarganegaraan baru Indonesia bagi terbinanya warga negara multidimensional Indonesia. Workshop on Civic Education Content Mapping. Bandung.

Willingham, D. T. (2008). Critical thinking: Why is it so hard to teach? Arts Education Policy Review, 109(4), 21-32. https://doi.org/10.3200/AEPR.109.4.21-32 